\title{
Prevalence and characteristics of chronic pain in Brazil: a national internet-based survey study
}

\author{
Prevalência e características da dor crônica no Brasil: um estudo nacional baseado em \\ questionário pela internet
}

Ravena Carolina de Carvalho', Caio Bustamante Maglioni', Gabriel Barbosa Machado', João Eduardo de Araújo², Josie Resende Torres da Silva ${ }^{1}$, Marcelo Lourenço da Silva ${ }^{1}$

DOI 10.5935/2595-0118.20180063

\section{ABSTRACT}

BACKGROUND AND OBJECTIVES: The prevalence of chronic pain has been increasing in the world, and it is considered the most underestimated health care problem impacting the quality of life. Furthermore, there is little consensus regarding the burden of chronic pain in Brazil. The present study aimed to investigate the prevalence of chronic pain in the general Brazilian adult population, and the socio-demographic, clinical, medical conditions and pain locations on the body.

METHODS: A cross-sectional Internet-based survey was conducted in a nationally representative sample of Brazil adults to estimate the prevalence, sociodemographic correlates and characteristics of chronic pain in the Brazilian population. Twenty-seven-thousand and three hundred forty-five $(27,345)$ representative residents were contacted.

RESULTS: From 27,345 individuals, 20,830 (76.17\%) presented chronic, recurrent, or long-lasting pain, lasting for at least 6 months. Nearly half of the respondents were 65 years older (48.15\%) and the prevalence was higher in females $(84,60 \%)$ than males $(16.40 \%)$. The prevalence of primary chronic lower back pain was $59.85 \%$; of primary rheumatoid arthritis was $(59.78 \%)$ and primary osteoarthritis pain was $69.02 \%$. Half of the respondents with chronic pain experienced daily pain, and average (past 3 months) pain intensity was moderate at $57.28 \%$. CONCLUSION: Chronic pain affects more than two-thirds of the population of Brazil. Our findings revealed a high prevalence and severity of chronic pain and suggested that it is a public health problem in Brazil. Risk factors are being a woman, advanced age and low levels of household income. There is a need for improved health policies in Brazil for patients with chronic pain. Keywords: Brazil, Chronic pain, Epidemiology, Pain, Prevalence.

1. Universidade Federal de Alfenas, Instituto de Ciências da Motricidade, Alfenas, MG, Brasil. 2. Universidade de Sáo Paulo, Faculdade de Medicina de Ribeirão Preto, Departamento de Biomecânica, Medicina e Reabilitação do Aparelho Locomotor, Ribeirăo Preto, SP, Brasil.

Submitted on May 17, 2018.

Accepted for publication on September 06, 2018.

Conflict of interests: none - Sponsoring sources: none.

Correspondence to:

Av. Jovino Fernandes Sales 2600

37130-000 Alfenas, MG, Brasil.

E-mail: lourencoms@uol.com.br

(C) Sociedade Brasileira para o Estudo da Dor

\section{RESUMO}

JUSTIFICATIVA E OBJETIVOS: A prevalência de dor crônica tem aumentado no mundo e é considerada o problema de saúde mais subestimado, com impacto na qualidade de vida. Além disso, há pouco consenso em relação à carga da dor crônica ao sistema de saúde no Brasil. O presente estudo teve como objetivo investigar a prevalência de dor crônica na população adulta geral brasileira e as condiçóes sociodemográficas, clínicas, médicas e a localização corporal da dor.

METODOS: Foi realizado um estudo transversal, em questionário pela internet em uma amostra nacionalmente representativa de adultos do Brasil, para estimar a prevalência e características da dor crônica na população brasileira. Vinte e sete mil e trezentos e quarenta e cinco (27.345) residentes representativos foram contatados.

RESULTADOS: Dos 27.345 indivíduos, 20.830 (76,17\%) apresentaram dor crônica, recorrente ou duradoura com duração de pelo menos 6 meses. Quase metade dos entrevistados tinham mais de 65 anos de idade $(48,15 \%)$ e a prevalência era maior nas mulheres $(84,60 \%)$ do que nos homens $(16,40 \%)$. A prevalência de dor lombar crônica primária foi de 59,85\%; de artrite reumatoide primária foi $(59,78 \%)$ e dor primária oriunda de osteoartrite foi de 69,02\%. Metade dos entrevistados com dor crônica apresentava dor diária e a intensidade da dor média (últimos 3 meses) era moderada em 57,28\%.

CONCLUSÁO: A dor crônica afeta mais de dois terços da populaçáo do Brasil. Os resultados deste estudo revelaram alta prevalência da dor crônica. Os fatores de risco são ser mulher, idade avançada e baixos níveis de renda familiar. Há necessidade de melhores políticas de saúde para pacientes com dor crônica no Brasil.

Descritores: Brasil, Dor, Dor crônica, Epidemiologia, Prevalência

\section{INTRODUCTION}

Chronic pain (CP) is a common problem, as well as its high prevalence, treatment, and economic costs, generating a negative impact on physical and psychological health ${ }^{1,2}$. CP is commonly regarded as a multidimensional phenomenon that involves physical, psychological, and sociocultural aspects and impacts the individual's health and well-being, health care services, and the society ${ }^{1}$. Some research groups in different countries have attempted to improve the understanding of the multiple characteristics of $\mathrm{CP}$, including its prevalence. 
Globally, it has been estimated that $25 \%$ of adults suffer from pain and that another $10 \%$ of adults are diagnosed with CP each year. While pain affects all populations, regardless of age, gender, income, race/ethnicity, or geography, it is not distributed equally across the globe ${ }^{2}$. Previous epidemiological studies of the general population have shown that the worldwide variability in the prevalence of pain could be partially explained by methodological, racial/ethnic, or cultural differences that ranged from $8.7 \%$ in Singapore ${ }^{3}$ to $48 \%$ in the $\mathrm{UK}^{4}$. In addition, some countries, as Australia, the UK, and the USA, started to use the convening of Pain Summits because those national governments have started to recognize that $\mathrm{CP}$ represents one of the main challenges and priorities for public health ${ }^{5-8}$.

In low-income and middle-income countries, the prevalence of pain is consistent with the Global Burden of Disease (GBD) data, with higher rates in the elderly general population and workers than in the general adult population. $28 \%$ of the GBD that could be averted by surgery and safe anesthesia might also be related to the CP burden. Trauma, cancer, birth complications, congenital defects, and other surgical diseases potentially lead to $\mathrm{CP}$ if not treated or if treated inadequately. This meta-analysis shows the range of $\mathrm{CP}$ in low-income and middle-income countries but has fallen short of revealing clear causes for the pain? $\mathrm{CP}$ represented by conditions such as low back pain and osteoarthritis has recently been highlighted as one of the most prominent causes of disability worldwide by the GBD reviews ${ }^{10}$.

There is limited information available on CP in Latin America. A community-based study conducted in Colombia reported that the prevalence of $\mathrm{CP}$ among the local adult population was $31 \%{ }^{11}$. In Brazil, in Londrina city, the prevalence of $\mathrm{CP}$ in the elderly was $51.44 \%{ }^{12}$. In Salvador city, the presence of CP was found in $41.4 \%$ of the population ${ }^{13}$. In São Luís city, a cross-sectional, population-based study, showed a predominance of $\mathrm{CP}$ of $50 \%$ in women, age bracket of 18 to 29 years, and brown skin color ${ }^{14}$. A São Paulo city population-based study showed that $28.7 \%$ of the surveyed reported pain lasting more than three months ${ }^{15}$. In the city of Florianópolis, $29.3 \%$ of older adults experienced $\mathrm{CP}^{16}$. Recently, in a cross-sectional study based on a population survey in the city of Bauru, a total number of 600 individuals were interviewed to determine the prevalence of neck pain and associated factors in adults and found the prevalence of $20.3 \%{ }^{17}$. While these results are significant, it is hard to draw conclusions from the results due to the lack of representation in the studies' sample populations.

This cross-sectional study provided quantitative data on the prevalence and severity of various kinds of $\mathrm{CP}$, the demographic characteristics of individuals with pain, the impact of pain on work, and the relationships with CP. This first national population-based study was needed to examine the prevalence of $\mathrm{CP}$ among the Brazilian population and to reconcile the widely variable estimates of the prevalence of $\mathrm{CP}$ in Brazil. We conducted a population-based survey of a representative sample of adults using an internet-administered survey ${ }^{18}$.

The demonstration of the prevalence of $\mathrm{CP}$ is essential as the era of global surgery begins, to allow benchmarking of this prevalence in the future as emergency and essential surgery services are expanded in several countries.
This study aimed to investigate: (1) the prevalence of CP in the general Brazilian adult population, and (2) the socio-demographic, clinical, medical conditions responsible for the pain and body locations of pain.

\section{METHODS}

After reading and agreed to the term of Consent electronically, adults aged 18 years older or more were eligible to participate in the current study. Participants were recruited through social media and pain management specialists and associations. The survey was conducted from September 2015 to July 2016. The Raosoft software (Federal Way, Washington, USA) was used to calculate the number of people required to be screened to detect a $50 \%$ prevalence of pain, with a $3 \%$ margin of error ( $95 \%$ power at the $5 \%$ significant level). A total of 1,068 people was required. Considering that the study focused on factors associated with the prevalence of $\mathrm{CP}$, the sample was increased to 2,136 adults.

\section{Classification of chronic pain}

Usually, pain is regarded as chronic when it lasts or recurs for more than 3 to 6 months ${ }^{19}$. We used a slightly more restrictive definition of $\mathrm{CP}$ as persistent or regularly recurrent pain with a duration of more than 6 months ${ }^{18,20}$.

This study was conducted using a simple online questionnaire prepared as a Google Forms survey asking up to 20 questions in Portuguese adapted from Johannes et al. ${ }^{18}$ : (1) "Do you have any chronic, recurrent, or long-lasting pain, more than aches and pains that are fleeting and minor"?/and those with an affirmative response were asked: (2) How long the pain was experienced? Respondents with chronic, recurrent, or long-lasting pain lasting for at least six months met the study definition of $\mathrm{CP}$ and continued with the survey. In sequence, (3) Gender, (4) Age, (5) Race, (6) Education level, (7) Marital status, (8) Household income, (9) Region, (10) Employment status/ (11) Internet access, (12) Metropolitan area, (13) Checklist to capture self-reported physician-diagnosed medical conditions for the current CP, (14) Body locations of the pain. Those indicating more than one medical condition were asked to (15) Specify the primary pain concern. Finally, questions about (16) Duration of primary CP, (17) The frequency of pain, (18) Average pain intensity in the past three months, (19) Worst pain intensity in the past three months, (20) If they take medication for the condition. For all respondents, a table was constructed for age, sex, race/ethnicity, education, region, metropolitan area, Internet accessibility, the frequency of physician-diagnosed pain conditions.

Before the implementation of the survey, a pilot study was carried out using a random age-stratified sample of 100 persons over a 3-month period. The goal was testing the survey functionality to evaluate the length of time for questionnaire completion, and to estimate the response rate.

This study had the approval of the Research Ethics Committee of the Instituition (CAEE: 46727215.7.0000.5142), Process Number 1.189 .406 of 2015 . 


\section{Statistical analysis}

The questionnaire responses were entered into the Microsoft Excel, and the data were analyzed with SPSS (version 21.0 for Windows, IBM Corp., Armonk, NY, USA). $\chi^{2}$ tests were used to test for associations between the sociodemographic variables and the questionnaire responses. To identify the sociodemographic factors that were associated with CP, odds ratios, 95\% CI, and $\mathrm{p}$ values were calculated. Continuous data are reported as

Table 1. Prevalence rates of chronic pain

\begin{tabular}{lcc}
\hline Characteristics & \multicolumn{2}{c}{ Groups } \\
& $\begin{array}{c}\text { Number of } \\
\text { participants }\end{array}$ & $\begin{array}{c}\% \text { of } \\
\text { total }\end{array}$ \\
\hline No pain & 27,345 & 100 \\
Chronic, recurrent, or long-lasting pain & 6,515 & 23.83 \\
Pain with a duration of $>6$ months & 20,830 & 76.17 \\
Pain for less than six months & 17,553 & 64.19 \\
Pain for at least three months & 1,383 & 5.06 \\
Pain for less than two months & 413 & 1.51 \\
\hline
\end{tabular}

the median and interquartile range (IQR) because variables had abnormal distribution according to Kolmogorov Smirnov test. Categorical data are represented as a percentage.

\section{RESULTS}

CP was defined as a "yes" answer to the question, "Do you have any chronic, recurrent, or long-lasting pain, more than aches and pains that are fleeting and minor"? A total of 20,830 (76.16\%) persons completed the first screening question indicating that they had chronic, recurrent, or long-lasting pain (Table 1). Table 2 shows that nearly half of the respondents were 65 years old, women, white, with a bachelor's degree or higher education. CP prevalence significantly increased when respondents have never married, with a household income level of less than $\mathrm{R} \$ 999$ a month, from the South region of Brazil.

The criteria for CP were met by 17,553 respondents and low back pain condition, and rheumatoid arthritis diagnosis were the most cited, respectively (Table 3 ).

Table 4 shows that the CP site most cited was the lower back, followed by knee, hand, and shoulder. Additionally, the overall

Table 2. Demographic characteristics of participants

\begin{tabular}{|c|c|c|c|c|}
\hline Characteristics & Chronic pain & Without chronic pain & OR $(95 \% \mathrm{Cl})$ & $\mathrm{p}$-value \\
\hline \multicolumn{5}{|l|}{ Gender n (\%) } \\
\hline Female & $14,674(84.60)$ & $8,024(81.94)$ & $1.23(1.05-1.19)$ & $<0.001$ \\
\hline \multicolumn{5}{|l|}{ Age group (years) n (\%) } \\
\hline $25-34$ & $1,062(6.05)$ & $481(4.91)$ & $0.94(0.81-1.10)$ & 0.500 \\
\hline $35-44$ & $1,546(8.81)$ & $659(6.73)$ & $1.01(0.87-1.16)$ & 0.900 \\
\hline $45-54$ & $1,727(9.84)$ & $738(7.54)$ & $1.01(0.87-1.15)$ & 0.092 \\
\hline $55-64$ & $3,658(20.84)$ & $2,843(29.03)$ & $1.80(1.60-2.03)$ & $<0,001$ \\
\hline $65+$ & $8,451(48.15)$ & $4,594(46.92)$ & $1.26(1.12-1.41)$ & $<0,001$ \\
\hline Black & $323(1.84)$ & $211(2.15)$ & $1.16(0.97-1.38)$ & 0.097 \\
\hline Yellow & $182(1.04)$ & $93(0.95)$ & $0.90(0.70-1.16)$ & 0.448 \\
\hline Indigenous & $123(0.70)$ & $67(0.68)$ & $0.96(0.71-1.30)$ & 0.827 \\
\hline \multicolumn{5}{|l|}{ Education level n (\%) } \\
\hline Some education & $5,932(33.79)$ & 3,266 (33.35) & Reference & \\
\hline High school & $4,629(26.37)$ & $1,781(18.19)$ & $0.69(0.65-0.74)$ & $<0.001$ \\
\hline Less than high school & $1,898(10.81)$ & $1,451(14.82)$ & $1.38(1.28-1.50)$ & $<0.001$ \\
\hline Bachelor's degree or higher & $5,094(29.02)$ & 3,294 (33.64) & $1.17(1.10-1.24)$ & $<0.001$ \\
\hline \multicolumn{5}{|l|}{ Marital status n (\%) } \\
\hline
\end{tabular}


Table 2. Demographic characteristics of participants - continuation

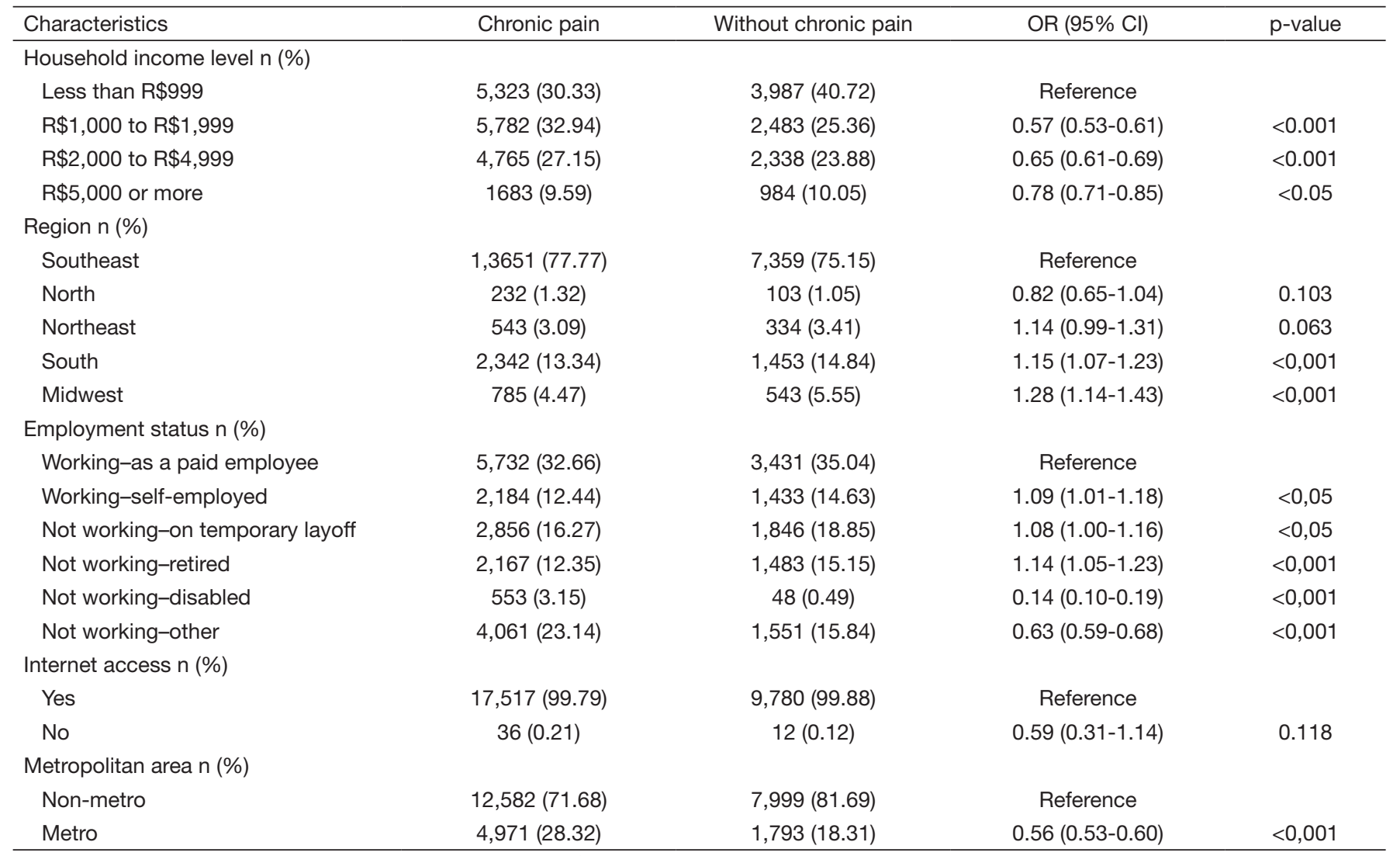

$\mathrm{OR}=$ Odds ratio; $\mathrm{Cl}=$ confidence interval; $\mathrm{p}$-value determined by $\mathrm{X}^{2}$ test.

Table 3. Frequency of self-reported physician-diagnosed pain condition or body location of pain among respondents with chronic pain of at least 6 months duration

\begin{tabular}{|c|c|c|c|}
\hline Pain category (condition or location) & $\begin{array}{l}\text { No. with each } \\
\text { pain category }\end{array}$ & $\begin{array}{l}\% \text { of each category } \\
\text { that was primary pain }\end{array}$ & $\begin{array}{c}\% \text { of each primary pain }{ }^{\dagger} \text { category contributing } \\
\text { to the overall point prevalence }\end{array}$ \\
\hline \multicolumn{4}{|l|}{ Physician-diagnosed pain condition } \\
\hline Low back pain & 5,343 & 59.85 & 18 \\
\hline Osteoarthritis & 1,614 & 69.02 & 6 \\
\hline Rheumatoid arthritis & 5,331 & 59.78 & 18 \\
\hline Migraine & 2,792 & 35.60 & 6 \\
\hline Carpal tunnel syndrome & 233 & 21.30 & $<1$ \\
\hline Fibromyalgia & 823 & 54.60 & 3 \\
\hline Chronic daily headaches or tension-type & 833 & 24.65 & 1 \\
\hline Diabetic peripheral neuropathy & 17 & 40.09 & $<1$ \\
\hline Ankylosing spondylitis & 22 & 40.12 & $<1$ \\
\hline Cancer-related pain & 23 & 50.13 & $<1$ \\
\hline Psoriatic arthropathy & 142 & 50.79 & $<1$ \\
\hline Postherpetic neuralgia & 43 & 15.24 & $<1$ \\
\hline Trigeminal neuralgia & 32 & 13.18 & $<1$ \\
\hline Others & 653 & 22.65 & 1 \\
\hline \multicolumn{4}{|l|}{ Body location of chronic pain } \\
\hline Head & 4,232 & 32 & 8 \\
\hline Face/mouth (includes jaw) & 1,366 & 11 & 1 \\
\hline Neck & 4,152 & 10 & 2 \\
\hline Upper back & 4,564 & 43 & 11 \\
\hline Mid back & 2,655 & 25 & 4 \\
\hline Lower back & 7,613 & 35 & 15 \\
\hline
\end{tabular}


Table 3. Frequency of self-reported physician-diagnosed pain condition or body location of pain among respondents with chronic pain of at least 6 months duration - continuation

\begin{tabular}{|c|c|c|c|}
\hline Pain category (condition or location) & $\begin{array}{l}\text { No. with each } \\
\text { pain category }\end{array}$ & $\begin{array}{l}\% \text { of each category } \\
\text { that was primary pain }\end{array}$ & $\begin{array}{c}\% \text { of each primary pain }{ }^{\dagger} \text { category contributing } \\
\text { to the overall point prevalence }\end{array}$ \\
\hline \multicolumn{4}{|l|}{ Body location of chronic pain } \\
\hline Chest (includes angina pectoris) & 937 & 12 & 1 \\
\hline Stomach/abdomen & 2,044 & 10 & 1 \\
\hline Pelvis/groin & 1,546 & 8 & 1 \\
\hline \multicolumn{4}{|l|}{ Joints } \\
\hline Hip(s) & 4,807 & 39 & 11 \\
\hline Knee(s) & 6,026 & 39 & 13 \\
\hline Ankle & 4,344 & 10 & 2 \\
\hline Feet & 4,565 & 23 & 6 \\
\hline Shoulder & 5,506 & 10 & 3 \\
\hline Elbow(s) & 4,108 & 4 & 1 \\
\hline Wrist(s) & 5,039 & 35 & 10 \\
\hline Hand(s) & 5,985 & 19 & 6 \\
\hline Other joint & 437 & 0 & $<1$ \\
\hline Hip (other than joint pain) & 1,478 & 1 & $<1$ \\
\hline Leg(s) or feet (other than joint pain) & 2,544 & 8 & 1 \\
\hline Shoulder (other than joint pain) & 1,873 & 9 & 1 \\
\hline $\operatorname{Arm}(\mathrm{s})$ or hand(s) (other than joint pain) & 1,878 & 25 & 3 \\
\hline Other & 951 & 33 & 2 \\
\hline \multicolumn{4}{|c|}{$\begin{array}{l}\text { TRespondents could check multiple pain conditions and locations; ₹Primary Pain is defined as the pain the respondent would most like to relieve that has lasted at } \\
\text { least } 6 \text { months. Respondents could choose only } 1 \text { pain condition or location as primary pain; \$Percentages were calculated using the number of respondents with } \\
\text { CP for at least } 6 \text { months as a denominator. }\end{array}$} \\
\hline Characteristics & & Number of participants & $\%$ total \\
\hline Duration of primary chronic pain & & 17,553 & 100 \\
\hline At least 6 months but less than 1 year & & 3,562 & 20.29 \\
\hline 1 year or more & & 13,991 & 79.71 \\
\hline \multicolumn{4}{|l|}{ Frequency of pain } \\
\hline Daily & & 8,731 & 49.74 \\
\hline Not daily, but more days than not & & 5,282 & 30.09 \\
\hline 2-3 times a week & & 221 & 1.26 \\
\hline Once a week & & 412 & 2.35 \\
\hline 2-3 times a month & & 722 & 4.11 \\
\hline Once a month & & 1,016 & 5.79 \\
\hline Less than once a month & & 717 & 4.08 \\
\hline Others & & 452 & 2.58 \\
\hline \multicolumn{4}{|l|}{ Average pain intensity in the past 3 months } \\
\hline Mild (0-3) & & 2,435 & 13.87 \\
\hline Moderate (4-6) & & 10,055 & 57.28 \\
\hline Severe $(7-10)$ & & 5,063 & 28.84 \\
\hline \multicolumn{4}{|l|}{ Worst pain intensity in the past 3 months } \\
\hline Mild (0-3) & & 925 & 5.27 \\
\hline Moderate (4-6) & & 7,656 & 43.62 \\
\hline Severe $(7-10)$ & & 8,972 & 51.11 \\
\hline \multicolumn{4}{|l|}{ Use of medications for the last pain episode } \\
\hline No & & 2,543 & 14.49 \\
\hline Painkiller & & 4,794 & 27.31 \\
\hline NSAIDs & & 7,065 & 40.25 \\
\hline Others & & 3,151 & 17.95 \\
\hline
\end{tabular}

NSAIDs = Nonsteroidal anti-inflammatory drugs. 
average intensity of the primary pain in the past 3 months was moderate, followed by severe and mild. Furthermore, the respondents took more NSAIDs and analgesic medication for the previously experienced pain, respectively.

\section{DISCUSSION}

This study is the first population-based prevalence survey of CP using cross-sectional Internet-based survey and suggests that $76 \%$ of the Brazilian population suffer from chronic pain, and the most prevalent pain is in the lower back, followed by the knee, hand, and shoulder.

In comparing our results with other population-based surveys conducted in Brazil, our overall prevalence is higher to that reported in Salvador city (prevalence of $41.4 \%$ ) by Sá et al. ${ }^{13}$, in São Paulo city (prevalence of $28.7 \%$ ) by Cabral et al. ${ }^{15}$ and in elderly people in the city of Florianópolis (prevalence of 29.3\%) by dos Santos et al. ${ }^{16}$. The different results from these studies could be attributed to data collection methods and CP definitions that were different in each of the three published city studies and differed from our Internet-based survey. Nevertheless, understanding the prevalence, causes and consequences of CP in the Brazilian population has the potential to improve the allocation and utilization of health care resources and federal and state public policies in promoting pain management ${ }^{2}$.

Our results are higher than previous estimates of chronic-pain prevalence in general population studies. The prevalence of CP reported in different studies varies a great deal, potentially being influenced by differences in the survey method, country or the definition of CP used. In fact, our overall prevalence estimate is twice higher to that reported by Johannes et al. ${ }^{18}$ in the U.S. (prevalence of 30.7\%) and Denmark (prevalence of 26.8\%) ${ }^{21}$ with similar CP definition and survey. Higher to that reported in the Chinese population (prevalence of $35.9 \%$ ) by Chen et al. ${ }^{22}$ in Japan (prevalence of 39.3\%) by Inoue et al. ${ }^{20}$ and in Scotland (prevalence of 50\%) by Elliot et al. ${ }^{23}$ in China, Japan and Scotland they defined CP using three or more months duration, whereas the U.S. and Denmark used six or more months. Although the International Association for the Study of Pain (IASP) definition of CP is 3 or more months duration, we used a slightly more restrictive definition of $\mathrm{CP}$, as a persistent or regularly recurrent pain with a duration of $>6$ months ${ }^{18,20}$. Moreover, despite our survey of CP being of open access, our participants were recruited through social media and pain management specialists and associations, and therefore, more respondents with pain may have been influenced to answer the survey and may influence the response bias.

Similar to other published research, we observed that the overall prevalence of CP was higher in females than in males. Research evidence supports gender-based differences in pain experience, including a higher prevalence and severity of CP in women ${ }^{24}$. Similar results were found in all regional studies in the cities of São Paulo ${ }^{15}$, Florianopolis ${ }^{16}$ and Salvador ${ }^{13}$.

The present findings provide more evidence that this trend is universal. The differences have often been explained as having to do with social and cultural factors and the varying effects of different male and female hormones on the body and, recently, the different types of immune cell to process $\mathrm{CP}$, microglia in male and T-cell in female mice. This difference was linked to testosterone, which could make $\mathrm{T}$ cells less able to mediate pain in the males, leading to their use of microglia instead ${ }^{25}$.

Consistent with other CP surveys ${ }^{26-28}$; we found an increase in the overall prevalence of CP with aging. In most studies, the larger increase in $\mathrm{CP}$ prevalence occurs during the fourth or fifth decade of life and might be associated with the progression of degenerative changes in the musculoskeletal system ${ }^{29}$. Even though, the evidence for an age-related decrease in pain tolerance threshold is much weaker than that for an increase in pain threshold ${ }^{30}$. The elderly population comprises the fastest growing segment of the world's population, and the complexity of pain assessment often requires a multidisciplinary approach to diagnosis and management. The pain physician should work together with a psychologist or psychiatrist; and the physical therapist should be part of the team as well, to help with functionality ${ }^{31}$.

Interesting relationships between CP and family structure were observed. Previous studies have reported that individuals living alone, or who are divorced, have a higher prevalence of musculoskeletal pain ${ }^{2032,33}$. We found that people living alone report more CP. Sá et al. ${ }^{13}$ also found a higher prevalence of CP in divorced and widowed individuals basically because divorce and widowhood involve social factors that may aggravate the appearance of CP.

$\mathrm{CP}$ is more prevalent in less privileged segments of the population, and factors that are associated with a lower socioeconomic level are consistently associated with an increase in $\mathrm{CP}^{14}$. The relation of poorer socioeconomic status indicators with $\mathrm{CP}$ is a consistent theme in the literature, and in particular, strong correlations have been observed between unemployment because of disability or health reasons and the presence of $\mathrm{CP}^{18,34,35}$. In our data, the odds of CP were increased among those in the lowest level of household income (also reported by previous studies $)^{15,22,36,37}$. Longitudinal data is necessary to explore the temporal association between work-related disability, income, and $\mathrm{CP}$ to determine whether these are risk factors for or consequences of CP.

CP prevalence was higher in the Midwest, South and Northeastern regions, although participants with $\mathrm{CP}$ in the Southeast region accounted for $77.77 \%$ of total CP patients of the Brazilian sample. The Northeastern region had the lowest CP prevalence rate.

Brazilian Northern and Northeastern regions are classified by human development index as less favored regions with regard to life expectancy, education level, and per capita income, as compared to the South and Southeastern regions. Despite this, the Northeastern region has lower pain prevalence. In a way, these data are conflicting with the epidemiologic results of the association of $\mathrm{CP}$ and socioeconomic factors, where low income and low education level are risk factors ${ }^{38}$.

Unemployed showed a higher prevalence of CP, similarly to self-employed compared to paid-employee. The Brazilian constitution considers an employee as any individual providing services, depending on and receiving a salary from an employer on a regular basis. A self-employed individual is defined as a private person that provides services to one or more companies, 
without employment relations. Although employed people can suffer from CP, especially work-related lower back pain, unemployment generates concerns in people, especially in relation to family stability, thereby exacerbating $\mathrm{CP}^{39}$. This can explain the higher prevalence of $\mathrm{CP}$ among unemployed.

Moreover, self-employed means that the service being provided is sporadic, there is no hierarchical subordination, and there is no monthly salary. As a self-employed, the individual provides services at their own costs and risks, without fixed working hours or subordination, they have no rights to regular benefits, such as paid vacations, health insurance, meals or transportation. This can explain the higher prevalence of $\mathrm{CP}$ among self-employed. The main causes of CP in Brazil were back pain, rheumatoid arthritis, headaches, and osteoarthritis and it is similar to other CP surveys ${ }^{18,40,41}$. Furthermore, in agreement with other studies $^{15,42,43}$, we found that the lower back $(35 \%)$ is the most common pain location. About $80 \%$ of adults experience low back pain at some point in their life ${ }^{44}$. Additionally, low back pain is the most common cause of job-related disability and a leading contributor to missed work days ${ }^{45}$. Pain can begin abruptly as a result of an accident or by lifting something heavy, or it can develop over time due to age-related changes of the spine. Sedentary lifestyles also can set the stage for low back pain, especially when a weekday routine of getting too little exercise is punctuated by strenuous weekend workout ${ }^{46}$.

Our results are consistent with other inquiries and suggest a considerable public health load of CP in Brazil, with about two-thirds of the population reporting $\mathrm{CP}$ that has lasted at least 6 months and about $85 \%$ individuals reporting pain of moderate-to-severe intensity in the past 3 months. The high prevalence of $\mathrm{CP}$ and its negative societal burden provide justification for regarding $\mathrm{CP}$ as a public health priority ${ }^{47}$.

The undertreatment of pain, a persistent problem for underdeveloped countries, only can be reduced with better diagnosis and treatment applied from a public health framework. Understanding pain as a disease may reduce the burden and its co-morbid conditions as well as potentially decrease the undertreatment and misdiagnosis of pain ${ }^{2,48}$.

Overall, the majority has taken nonsteroidal anti-inflammatory drugs (NSAIDs) $(7,065,40.25 \%)$ at the time of the survey for CP management. NSAIDs are not recommended for long-term use, and careful surveillance to monitor for toxicity and efficacy is $\mathrm{critical}^{49}$. Although NSAIDs use was most prevalent across Brazil, $91 \%$ in Finland ${ }^{41}$ or $95 \%$ in India ${ }^{50}$ survey's respondents were taking NSAIDs. Hence, the risks from chronic use of NSAIDs are significant in CP management. They can cause life-threatening ulcers and gastrointestinal bleeding, a side-effect that occurs more frequently and with greater severity as people age ${ }^{51}$.

This study does have several limitations. The estimate of CP in the general population relies on recall of pain status during a defined period of time and is susceptible to recall bias. Moreover, pain data were self-reported which can be imprecise and subject to reporting bias, particularly in elderly respondents (69\% were 55 years old or more) who may have communication difficulties and possible were helped by other members of the house, which may have influenced their responses. Another aspect is related to internet access among the Brazilian population of different social and economic conditions, living in the different geographical regions of the country. The questionnaire was online, and the participants used the internet to answer the questions. Therefore, $99.79 \%$ of CP responses was that they have "internet access".

Furthermore, despite Brazil's continental dimension and wide climate diversification, influenced by its geographical configuration, we did not focus on the relationship between $\mathrm{CP}$ and the climate or environmental situation in this study. Finally, there are no validated tools for assessing self-reported pain, and because pain is a subjective experience, assessments of self-reported pain intensity, duration, and frequency are considered acceptable. Similarly, we relied on self-reports for diagnoses of medical conditions, and we were unable to check this information. Nevertheless, the Internet-based survey methodology was an efficient way to reach a large sample of Brazil's population, with demographic information available for the entire panel allowing for comparison of people with and without $\mathrm{CP}$.

\section{CONCLUSION}

Our results are generally consistent with other surveys and suggest a considerable public health burden of CP in Brazil, with two-thirds of the population reporting $\mathrm{CP}$ that has lasted at least 6 months and about a third of individuals reporting pain of severe intensity in the past 3 months. There is a need for improved pain management policies in Brazil to ensure that patients with $\mathrm{CP}$ receive effective treatment.

\section{ACKNOWLEDGMENTS}

This work was supported by the Federal University of Alfenas UNIFAL-MG and Fundação de Amparo à Pesquisa de Minas Gerais - FAPEMIG (Scientific Initiation Scholarship Program fellowship, Caio Bustamante Maglioni). We are grateful for the excellent technical support from Dr. Luciana Costa Teodoro and the contribution of Dr. Renato Leonardo de Freitas and Dr. José Aparecido da Silva.

\section{REFERENCES}

1. Gureje O, Von Korff M, Simon GE, Gater R. Persistent pain and well-being: a World Health Organization Study in Primary Care. JAMA. 1998;280(2):147-51.

2. Goldberg DS, McGee SJ. Pain as a global public health priority. BMC Public Health 2011;11:770.

3. Currow DC, Agar M, Plummer JL, Blyth FM, Abernethy AP. Chronic pain in South Australia - population levels that interfere extremely with activities of daily living. Aust N Z J Public Health. 2010;34(3):232-9.

4. Torrance N, Smith BH, Bennett MI, Lee AJ. The epidemiology of chronic pain of predominantly neuropathic origin. Results from a general population survey. J Pain. 2006;7(4):281-9.

5. USG. DoHaHS. National Pain Strategy: a comprehensive population health strategy for pain, http://iprcc.nih.gov/docs/DraftHHSNationalPainStrategy.pdf 2015.

6. Committee on Advancing Pain Research $\mathrm{C}$ aEBoHSPIoM. Relieving pain in America: a blueprint for transforming prevention, care, education and research. http://www. nap.edu/catalog/13172/relieving-painin-america-a-blueprint-for-transforming-prevention-care (accessed Feb 2016). 2011.

7. Strategy TNP. http://www.painaustralia.org.au/ the-national-pain-strategy/national-pain-strategy.html (accessed Feb 2016). 2010.

8. LJ. D. Pain: breaking through the barrier. 150 years of the Annual Report of the Chief Medical Officer: on the state of the public health. London. http://webarchive.nationalarchives.gov.uk/ 20130107105354/http://www.dh.gov.uk/en/Publicationsandsta- 
tistics/ Publications/AnnualReports/DH_096206. 2008.

9. Jackson T, Thomas S, Stabile V, Han X, Shotwell M, McQueen K. Prevalence of chronic pain in low-income and middle-income countries: a systematic review and meta-analysis. Lancet. 2015;385(Suppl 2):S10.

10. Vos T, Flaxman AD, Naghavi M, Lozano R, Michaud C, Ezzati M, et al. Years lived with disability (YLDs) for 1160 sequelae of 289 diseases and injuries 19902010: a systematic analysis for the Global Burden of Disease Study 2010. Lancet. 2012;380(9859):2163-96.

11. Cabezas RD, Mejía FM, Sáens X. Epidemiological study of chronic pain in Caldas, Colombia (Dolca Study). Acta Med Colomb. 2009;34(3):96-102.

12. Dellaroza MS, Pimenta CA, Matsuo T. [Prevalence and characterization of chronic pain among the elderly living in the community]. Cad Saude Publica. 2007;23(5):115160. Portuguese.

13. Sá K, Baptista AF, Matos MA, Lessa I. Prevalence of chronic pain and associated factors in the population of Salvador, Bahia. Rev Saude Publica. 2009;43(4):622-30. English, Portuguese.

14. Vieira EB, Garcia JB, Silva AA, Araújo RL, Jansen RC, Bertrand AL. Chronic pain, associated factors, and impact on daily life: are there differences between the sexes? Cad Saude Publica. 2012;28(8):1459-67.

15. Cabral DM, Bracher ES, Depintor JD, Eluf-Neto J. Chronic pain prevalence and associated factors in a segment of the population of Sao Paulo City. J Pain. 2014;15(11):1081-91.

16. dos Santos FA, de Souza JB, Antes DL, d'Orsi E. Prevalence of chronic pain and its association with the sociodemographic situation and physical activity in leisure of elderly in Florianopolis, Santa Catarina: population-based study. Rev Bras Epidemiol. 2015;18(1):234-47

17. Genebra C, Maciel NM, Bento TPF, Simeao S, Vitta A. Prevalence and factors associated with neck pain: a population-based study. Braz J Phys Ther. 2017;21(4):274-80.

18. Johannes CB, Le TK, Zhou X, Johnston JA, Dworkin RH. The prevalence of chronic pain in United States adults: results of an Internet-based survey. J Pain. 2010;11(11):1230-9.

19. Treede RD, Rief W, Barke A, Aziz Q, Bennett MI, Benoliel R, et al. A classification of chronic pain for ICD-11. Pain. 2015;156(6):1003-7.

20. Inoue S, Kobayashi F, Nishihara M, Arai YC, Ikemoto T, Kawai T, et al. Chronic pain in the Japanese community--prevalence, characteristics and impact on quality of life. PLoS One. 2015;10(6):e0129262.

21. Kurita GP, Sjøgren P, Juel K, Højsted J, Ekholm O. The burden of chronic pain: a cross-sectional survey focussing on diseases, immigration, and opioid use. Pain. 2012;153(12):2332-8.

22. Chen B, Li L, Donovan C, Gao Y, Ali G, Jiang Y, et al. Prevalence and characteristics of chronic body pain in China: a national study. Springerplus. 2016;5(1):938.

23. Elliott AM, Smith BH, Penny KI, Smith WC, Chambers WA. The epidemiology of chronic pain in the community. Lancet. 1999;354(9186):1248-52.

24. Fillingim RB, Edwards RR, Powell T. The relationship of sex and clinical pain to experimental pain responses. Pain. 1999;83(3):419-25.

25. Sorge RE, Mapplebeck JC, Rosen S, Beggs S, Taves S, Alexander JK, et al. Different immune cells mediate mechanical pain hypersensitivity in male and female mice. Nat Neurosci. 2015;18(8):1081-3.

26. Azevedo LF, Costa-Pereira A, Mendonça L, Dias CC, Castro-Lopes JM. Epidemiology of chronic pain: a population-based nationwide study on its prevalence, characteristics and associated disability in Portugal. J Pain. 2012;13(8):773-83.

27. Raftery MN, Sarma K, Murphy AW, De la Harpe D, Normand C, McGuire BE. Chronic pain in the Republic of Ireland--community prevalence, psychosocial profile and predictors of pain-related disability: results from the Prevalence, Impact and Cost of Chronic Pain (PRIME) study, part 1. Pain. 2011;152(5):1096-103.

28. Rustoen T, Wahl AK, Hanestad BR, Lerdal A, Paul S, Miaskowski C. Prevalence and characteristics of chronic pain in the general Norwegian population. Eur J Pain. 2004;8(6):555-65.

29. Mitchell C. Assessment and management of chronic pain in elderly people. Br J Nurs. 2001;10(5):296-304.

30. Lautenbacher S, Peters JH, Heesen M, Scheel J, Kunz M. Age changes in pain perception: a systematic-review and meta-analysis of age effects on pain and tolerance thresholds. Neurosci Biobehav Rev. 2017;75:104-13.

31. Lansbury G. Chronic pain management: a qualitative study of elderly people's preferred coping strategies and barriers to management. Disabil Rehabil. 2000;22(1-2):2-14.

32. Soares JJ, Sundin O, Grossi G. Age and musculoskeletal pain. Int J Behav Med. 2003;10(2):181-90.

33. Soares JJ, Jablonska B. Psychosocial experiences among primary care patients with and without musculoskeletal pain. Eur J Pain. 2004;8(1):79-89.

34. Blyth FM, March LM, Brnabic AJ, Jorm LR, Williamson M, Cousins MJ. Chronic pain in Australia: a prevalence study. Pain. 2001;89(2-3):127-34.

35. Dueñas M, Salazar A, Ojeda B, Fernandez-Palacin F, Mico JA, Torres LM, et al. A nationwide study of chronic pain prevalence in the general Spanish population: identifying clinical subgroups through cluster analysis. Pain Med. 2015;16(4):811-22.

36. Yeo SN, Tay KH. Pain prevalence in Singapore. Ann Acad Med Singapore. 2009;38(11):937-42.

37. de Sola H, Salazar A, Duenas M, Ojeda B, Failde I. Nationwide cross-sectional study of the impact of chronic pain on an individual's employment: relationship with the family and the social support. BMJ Open. 2016;6(12):e012246.

38. Shmagel A, Foley R, Ibrahim H. Epidemiology of chronic low back pain in US adults: data from the 2009-2010 National Health and Nutrition Examination Survey. Arthritis Care Res. 2016;68(11):1688-94.

39. Català E, Reig E, Artés M, Aliaga L, López J, Segú J. Prevalence of pain in the Spanish population: telephone survey in 5000 homes. Eur J Pain 2002;6(2):133-40.

40. Elzahaf RA, Johnson MI, Tashani OA. The epidemiology of chronic pain in Libya: a cross-sectional telephone survey. BMC Public Health. 2016;16(1):776.

41. Breivik H, Collett B, Ventafridda V, Cohen R, Gallacher D. Survey of chronic pain in Europe: prevalence, impact on daily life, and treatment. Eur J Pain. 2006;10(4):287-333.

42. Hardt J, Jacobsen C, Goldberg J, Nickel R, Buchwald D. Prevalence of chronic pain in a representative sample in the United States. Pain Med. 2008;9(7):803-12.

43. Wong WS, Fielding R. Prevalence and characteristics of chronic pain in the general population of Hong Kong. J Pain. 2011;12(2):236-45.

44. Refshauge KM, Maher CG. Low back pain investigations and prognosis: a review. $\mathrm{Br}$ J Sports Med. 2008;40(6):494-8.

45. Wynne-Jones G, Cowen J, Jordan JL, Uthman O, Main CJ, Glozier N, et al. Absence from work and return to work in people with back pain: a systematic review and meta-analysis. Occup Environ Med. 2014;71(6):448-56.

46. Almeida DC, Kraychete DC. Low back pain - a diagnostic approach. Rev Dor. 2017;18(2):173-7.

47. Ollila E. Global health priorities - priorities of the wealthy? Global Health. 2005;1(1):6.

48. Albuquerque MV, Viana AL, Lima LD, Ferreira MP, Fusaro ER, Iozzi FL. Regional health inequalities: changes observed in Brazil from 2000-2016. Cien Saude Colet. 2017;22(4):1055-64.

49. Ussai S, Miceli L, Pisa FE, Bednarova R, Giordano A, Della Rocca G, et al. Impact of potential inappropriate NSAIDs use in chronic pain. Drug Des Devel Ther. 2015;9:2073-7.

50. Dureja GP, Jain PN, Shetty N, Mandal SP, Prabhoo R, Joshi M, et al. Prevalence of chronic pain, impact on daily life, and treatment practices in India. Pain Pract. 2014;14(2):E51-62.

51. Sostres C, Gargallo CJ, Lanas A. Nonsteroidal anti-inflammatory drugs and upper and lower gastrointestinal mucosal damage. Arthritis Res Ther. 2013;15(Suppl 3):S3. 